WellBeing International

WBI Studies Repository

$12-27-2006$

\title{
Properties of Corneal Receptors in a Teleost Fish
}

\author{
Paul J. Ashley \\ University of Liverpool \\ Lynne U. Sneddon \\ University of Liverpool \\ Catherine R. McCrohan \\ University of Manchester
}

Follow this and additional works at: https://www.wellbeingintlstudiesrepository.org/acwp_vsm

Part of the Animal Studies Commons, Organismal Biological Physiology Commons, and the Other Animal Sciences Commons

\section{Recommended Citation}

Ashley, P. J., Sneddon, L. U., \& McCrohan, C. R. (2006). Properties of corneal receptors in a teleost fish. Neuroscience letters, 410(3), 165-168.

This material is brought to you for free and open access by WellBeing International. It has been accepted for inclusion by an authorized administrator of the WBI Studies Repository. For more information, please contact wbisr-info@wellbeingintl.org.

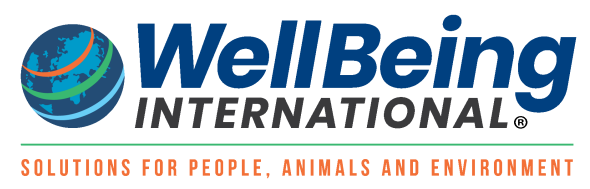




\title{
Properties of Corneal Receptors in a Teleost Fish
}

\author{
Paul J. Ashley ${ }^{1}$, Lynne U. Sneddon ${ }^{1}$, Catherine R. McCrohan ${ }^{2}$ \\ ${ }^{1}$ University of Liverpool \\ ${ }^{2}$ University of Manchester
}

KEYWORDS

Corneal receptors; Trigeminal ganglion; Oncoryhnchus mykiss

\begin{abstract}
Corneal receptors have not previously been identified in lower vertebrates. The present study describes the properties of trigeminal ganglion corneal receptors in a teleost fish, the rainbow trout (Oncoryhnchus mykiss). Out of 27 receptors, 7 were polymodal nociceptors, 6 were mechanothermal nociceptors, 2 were mechanochemical receptors and the largest group, 12, were only responsive to mechanical stimulation. No cold responsive receptors were found on the trout cornea. Mechanical and thermal thresholds were lower and receptive field diameters smaller than those of cutaneous trigeminal receptors in the trout, demonstrating greater sensitivity in the cornea. The lack of cold sensitive neurons may provide evidence for the evolution of cold nociceptors in vertebrates that is related to the transition from poikilothermy to homeothermy.
\end{abstract}

Corneal receptors have been well studied in mammals including humans [e.g. 1,7,11,12] with identification of three types: mechanosensitive receptors, polymodal nociceptors and cold sensitive nociceptors. All of these receptors are presumed to have a nociceptive function to protect the delicate cornea from damage and, as such, they have lower thresholds than cutaneous nociceptors. The cornea of the mammalian eye is supplied with free nerve endings in the outermost layers of the corneal epithelium, arising from peripheral axons of A-delta and $C$ fibres within the trigeminal nerve. The fish cornea shows similar innervation by free nerve endings from the trigeminal nerve, yet corneal nociceptors have not been identified or described in lower vertebrates [17]. Anatomical and electrophysiological investigations in the rainbow trout, a teleost fish, have shown that A-delta fibres predominate (25\%) with very few $C$ fibres $(4 \%)$ in the trigeminal afferents [12,14]. This suggests an evolutionary difference between the vertebrate groups, with A-delta fibres acting as polymodal nociceptors in teleosts whereas $\mathrm{C}$ fibres fulfill this function in mammals [8]. The present study aimed to identify and characterise trigeminal receptors in the cornea of a fish for the first time, and to relate any differences in physiological properties to differences in life history between fish and mammals. 
Experiments were conducted humanely and ethically under Home Office (UK) Guidelines. Rainbow trout (mean $123 \pm 9.52 \mathrm{~g} ; n=17$ ) were obtained from a commercial supplier and maintained in stock tanks (70 $\mathrm{cm} \times 70 \mathrm{~cm} \times 120 \mathrm{~cm} ; 155 \mathrm{gal} ; n=5$ fish per tank maximum) with a constant flow of filtered freshwater at $15 \pm 1^{\circ} \mathrm{C}$. The fish were fed ad libitum daily and kept on a $12: 12 \mathrm{~h}$ light:dark regime. Each tank was covered by an opaque lid and underwater shelters were also provided.

Fish were caught individually by netting and anaesthetized initially by immersion in benzocaine dosed water ( $1 \mathrm{ml} / \mathrm{l}$ of $1 \mathrm{~g} / 30 \mathrm{ml}$ ethanol; Sigma-Aldrich Co., UK) to facilitate weighing and intraperitoneal injection of Saffan $(0.3 \mathrm{ml} / 100 \mathrm{~g}$; Schering-Plough Animal Health, Welwyn Garden City, UK). Once surgical, deep plane anaesthesia was achieved, the fish was placed into a stainless steel cradle cushioned with polystyrene and wet paper towel and held in position with Velcro straps. This apparatus allowed the fish to be ventilated by flushing fresh water over the gills, by means of a tube held in place by a specially constructed mouth piece, from an aerated and temperature controlled circulation system (15 \pm $\left.1^{\circ} \mathrm{C}\right)$. Skin and bone were removed above the brain and the olfactory, and optic lobes and cerebellum were removed by suction. After decerebration, motor areas stimulated by the removal of brain tissue caused muscular twitching. Therefore, a neuromuscular blocker, Pavulon (pancurorium bromide $2 \mathrm{mg} / \mathrm{ml}$; Sigma-Aldrich, UK), was injected intramuscularly $(0.08 \mathrm{ml} / 100 \mathrm{~g})$ to prevent this. Bone was removed to expose the left trigeminal ganglion, which was desheathed and covered in paraffin to prevent moisture loss. Glass insulated tungsten microelectrodes (tip diameter $10 \mu \mathrm{m}, 200 \mathrm{~K} \Omega$ impedance, Royem Scientific Ltd., UK) were used to record from afferent cell bodies positioned centrally into the trigeminal ganglion where the cell bodies are located [14]. Extracellular action potentials were amplified using a NL100 head stage connected to a NL104 preamplifier (Neurolog System, Digitimer Ltd., UK). The signal was displayed on a storage oscilloscope (5113, Tektronix INC) and stored on a PC using a Micro 1401 interface and Spike 2 software (CED, UK). Following the application of stimuli to the cornea, evoked neural activity was recorded from single units in the trigeminal ganglion. A glass mechanical probe $(0.1 \mathrm{~mm}$ diameter) was lightly applied to the cornea in order to locate a receptive field. Once located, the diameter of the receptive field was measured to $0.1 \mathrm{~mm}$ using Vernier callipers and the mechanical threshold of the receptor was determined by applying a custom built mechanical stimulator to the receptive field. The mechanical stimulator consisted of a contact point with a flat head (1mm diameter) attached to a force transducer (range 0.0006-16.6 g) and micro-stepper motor allowing the probe to be advanced onto the cornea in increments. The mechanical threshold was the lowest force applied that gave a repeatable response from the receptive field. The receptor was then tested for thermal sensitivity. A custom built peltier driven thermode with a $1 \mathrm{~mm}$ diameter flat contact point was placed on the receptor field and temperature was raised to $41^{\circ} \mathrm{C}$. Temperature was measured by a thermocouple attached to the contact point and was controlled to $0.1^{\circ} \mathrm{C}$ by a driver feedback circuit. Heat stimulation was applied $\left(1.25^{\circ} \mathrm{C} / \mathrm{s}\right.$ from $15^{\circ} \mathrm{C}$ up to $41^{\circ} \mathrm{C}$ ) and the threshold was determined. Once a repeatable threshold response ( $\times$ ) was established the thermode temperature was returned to $15^{\circ} \mathrm{C}$. This procedure was repeated to establish cold thermal sensitivity by driving the thermode temperature from $15^{\circ} \mathrm{C}$ to $-7^{\circ} \mathrm{C}$ at a rate of $1.5^{\circ} \mathrm{C} / \mathrm{s}$. Once thermal sensitivities were established the thermode was returned to $15^{\circ} \mathrm{C}$ and then removed from the corneal surface. To ascertain chemosensitivity and since the protons of acid excite nociceptors, a single drop of $1 \%$ acetic acid was placed onto the skin at the centre of the receptive field. This stimulation was repeated to ensure a similar response was given to this stimulation by the receptive field. None of the receptors responded to a drop of water placed on the centre of the receptive field.

Spike 2 software allowed the following parameters of extracellularly recorded action potentials to be measured: spike shape (with or without inflexion); amplitude and duration; afterhyperpolarisation (AHP) amplitude and duration; maximum rate of depolarisation ( $\mathrm{d} V / \mathrm{d} t \mathrm{tmax}$ ), and peak firing rate at stimulus 
threshold for temperature, $1.5 \times$ threshold for mechanical stimulation and to the standard chemical stimulation. These parameters were compared using one-way analysis of variance (ANOVA).

Fig. 1. Diagram showing the locations of the different types of receptor on the eye of the rainbowtrout $(n=27$, $i=$ polymodal nociceptor,$\square=$ mechanothermal nociceptor, $\Delta=$ mechanoreceptor, $\mathrm{o}=$ mechanochemical receptor).

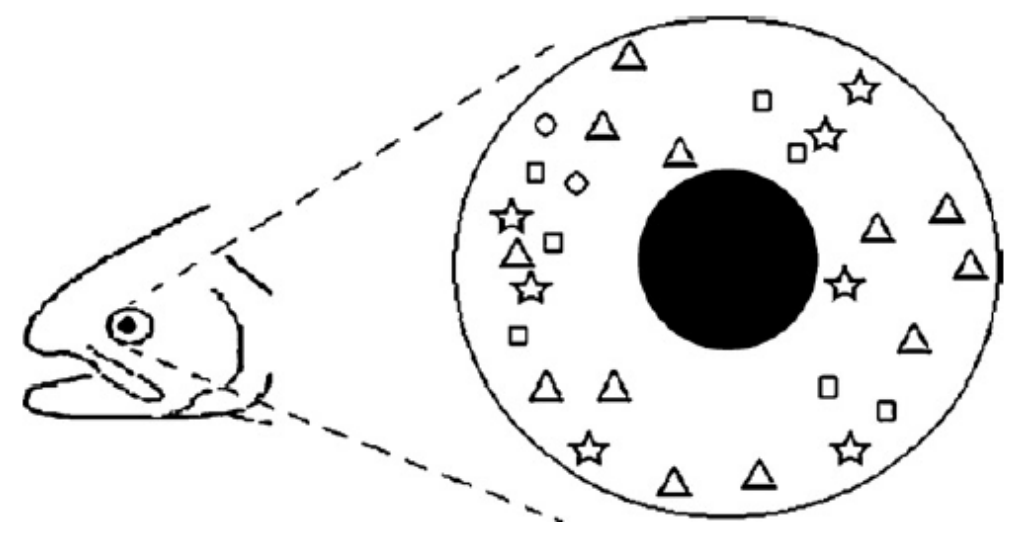

A total of 27 receptors were characterised from 17 fish (Fig. 1). Of these, seven were polymodal nociceptors, six were mechanothermal nociceptors, two responded to only mechanical and chemical stimulation and were termed mechanochemical receptors and 12 were mechanical receptors. Since we only found two mechanochemical receptors and these receptors are known to be rare in fish [14], we excluded their properties from the statistical analyses. Table 1 summarises the action potential and response properties. Action potential shape (no inflexion), amplitude and duration were similar for all receptor types. However, the amplitude of after-hyperpolarisation was significantly greater for polymodal nociceptors than for mechanosensitive receptors (main effect $F_{2,24}=4.59 ; p=0.021$ ). The polymodal nociceptors gave a slowly adapting response to mechanical stimulation and were responsive to thermal (heat) and chemical stimulation (Fig. 2). Mechanothermal nociceptors responded to heat and mechanical stimulation but not to chemical stimulation. Mechanochemical receptors did not respond to thermal stimulation but gave a slowly adapting response to mechanical stimulation and were sensitive to chemical stimulation. Mechanical receptors responded only to mechanical stimulation. None of the receptors responded to cold stimulation, i.e. below $4^{\circ} \mathrm{C}$. Receptive field diameters were similar for all receptor types, as were thresholds and peak firing rates for responses to either mechanical, chemical or heat stimuli (Table 1).

Fig. 2. Example of a corneal polymodal nociceptor showing no response to a drop of water, a slowly adapting response to mechanical stimulation and responses to heat; cold and chemical stimulation. 


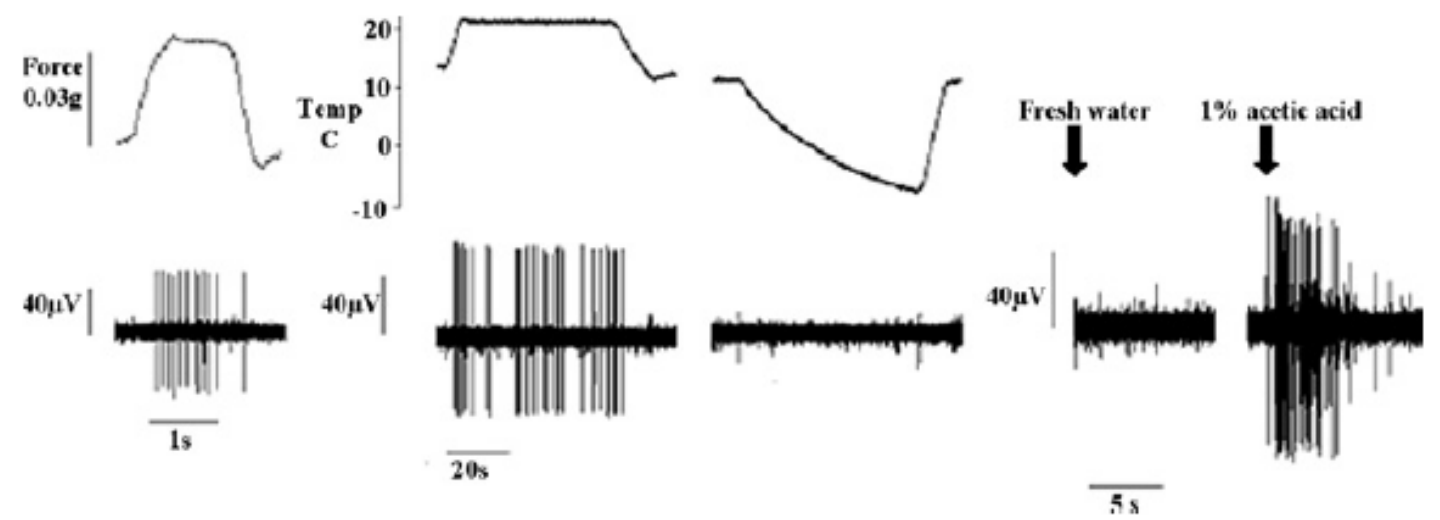

Table 1. Physiological properties of corneal receptive fields of the rainbow trout

\begin{tabular}{|c|c|c|c|c|c|}
\hline & Polymodal $(n=9)$ & Mechanical $(n=12)$ & Mechano-thermal $(n=6)$ & $\begin{array}{l}\text { Mechano-chemical } \\
(n=2)\end{array}$ & $\begin{array}{l}\text { Statistical } \\
\text { significance }\end{array}$ \\
\hline $\begin{array}{l}\text { Receptive field } \\
\text { diameter }(\mathrm{mm})\end{array}$ & $1.38 \pm 0.26(0.7-2.9)$ & $1.20 \pm 0.26(0.5-2.9)$ & $1.20 \pm 0.21(0.8-1.9)$ & $1.25(0.5-2.0)$ & $\begin{array}{l}F_{2,19}=0.16 \\
p=0.858\end{array}$ \\
\hline $\begin{array}{l}\text { Mechanical } \\
\text { threshold (g) }\end{array}$ & $\begin{array}{l}0.062 \pm 0.03(0.005- \\
0.299)\end{array}$ & $0.070 \pm 0.02(0.002-0.228)$ & $\begin{array}{l}0.050 \pm 0.02(0.008- \\
0.137)\end{array}$ & $0.216(0.042-0.390)$ & $\begin{array}{l}F_{2,23}=0.11 \\
p=0.892\end{array}$ \\
\hline $\begin{array}{l}\text { Temperature } \\
\text { threshold }\left({ }^{\circ} \mathrm{C}\right)\end{array}$ & $31.70 \pm 2.09(21.4-40.6)$ & & $36.05 \pm 1.15(31.8-39.0)$ & & $\begin{array}{l}F_{1,13}=2.50 \\
p=0.138\end{array}$ \\
\hline $\begin{array}{l}\text { Response to } \\
\text { chemical stimulation }\end{array}$ & $\sqrt{ }$ & $x$ & $x$ & $\sqrt{ }$ & N/A \\
\hline $\begin{array}{l}\text { Action potential } \\
\text { duration (ms) }\end{array}$ & $2.12 \pm 0.27(1.1-3.3)$ & $2.40 \pm 0.14(1.6-3.3)$ & $2.18 \pm 0.27(1.4-3.2)$ & $2.15(2.1-2.2)$ & $\begin{array}{l}F_{2,24}=0.52 \\
p=0.603\end{array}$ \\
\hline $\begin{array}{l}\text { Action potential } \\
\text { amplitude }(\mathrm{mV})\end{array}$ & $0.055 \pm 0.01(0.003-0.09)$ & $0.044 \pm 0.10(0.02-0.08)$ & $0.055 \pm 0.01(0.03-0.98)$ & $0.033(0.02-0.08)$ & $\begin{array}{l}F_{2,24}=0.98 \\
p=0.391\end{array}$ \\
\hline AHP amplitude (mV) & $0.034 \pm 0.01(0.01-0.09)$ & $0.012 \pm 0.01(0.01-0.02)$ & $0.019 \pm 0.003(0.01-0.03)$ & $0.025(0.02-0.04)$ & $\begin{array}{l}F_{2,24}=4.59 \\
p=0.021\end{array}$ \\
\hline AHP duration (ms) & $1.4 \pm 0.2(0.6-2.1)$ & $1.7 \pm 0.09(1.1-2.2)$ & $1.6 \pm 0.18(1.0-2.1)$ & $1.5(1.4-1.6)$ & $\begin{array}{l}F_{2,24}=1.03 \\
p=0.372\end{array}$ \\
\hline $\begin{array}{l}\mathrm{d} V / \mathrm{d} t m a x \text { max. rate } \\
\text { depolarisation }\end{array}$ & $0.097 \pm 0.02(0.03-0.17)$ & $0.069 \pm 0.01(0.03-0.14)$ & $0.120 \pm 0.03(0.05-0.26)$ & $0.055(0.03-0.06)$ & $\begin{array}{l}F_{2,24}=2.09 \\
p=0.145\end{array}$ \\
\hline $\begin{array}{l}\text { Peak firing rate } \\
\text { mechanical }\left(s^{-1}\right)\end{array}$ & $36.45 \pm 5.9(7.7-55.8)$ & $41.76 \pm 3.38(26.0-58.2)$ & $33.55 \pm 4.8(23.0-51.4)$ & $22.02(14.4-29.6)$ & $\begin{array}{l}F_{2,22}=0.80 \\
p=0.462\end{array}$ \\
\hline $\begin{array}{l}\text { Peak firing rate } \\
\text { thermal }\left(\mathrm{s}^{-1}\right)\end{array}$ & $14.74 \pm 1.6(5.6-19.7)$ & & $26.82 \pm 7.5(2.4-47.0)$ & & $\begin{array}{l}F_{1,13}=3.63 \\
p=0.079\end{array}$ \\
\hline $\begin{array}{l}\text { Peak firing rate } \\
\text { chemical }\left(\mathrm{s}^{-1}\right)\end{array}$ & $47.90 \pm 13.4(10.5-134.3)$ & & & $70.5(60-81)$ & N/A \\
\hline
\end{tabular}


This study provides the first demonstration of corneal nociceptors in fish. The properties of corneal receptors differ from those of cutaneous receptors in the trout [12,14]. Receptive field diameters were smaller, possibly due to the size of the eye relative to the skin of the head giving a smaller surface area for the free nerve endings of each neuron. Mechanical thresholds were also much lower in the cornea compared with cutaneous receptors, indicating greater sensitivity. Teleost fish do not have eyelids so the eye is constantly exposed to potentially damaging mechanical and chemical stimuli [4]. Fish also suffer eye lesions, corneal lesions, cataracts and eye parasites that result in stress and mortality $[2,4,5]$. Therefore, a low mechanical threshold would be advantageous to alert the fish to potential damage, enabling a swifter avoidance response. In mammals, mechanical thresholds are also lower in the cornea compared with cutaneous polymodal nociceptors [7]. However, in trout, the mechanical threshold of cutaneous polymodal nociceptors is similar to that found in the mammalian cornea [14], so that fish corneal receptors are more sensitive than mammalian corneal receptors. Fish are in constant contact with their aqueous environment and even slight damage caused by handling removes the mucus layer that covers the skin, increasing susceptibility to disease [3]. Eye lesions can result in high mortality and this may explain why the fish corneal receptors have a high sensitivity since damage to them may be especially detrimental [4]. Thermal thresholds are also apparently lower in the trout cornea compared with cutaneous receptors [14] suggesting increased sensitivity to heat in the cornea. However, this finding is more likely an artefact of the stimulation method. Sneddon [14] used a thermal stimulator placed $1 \mathrm{~mm}$ above the skin in order to avoid damage. In the present study, the thermal stimulator was placed directly in contact with the cornea and responses were measured at lower temperatures from 24 to $41^{\circ} \mathrm{C}$; above the latter, damage occurred and no further recordings could be made. Our recent testing of cutaneous receptors using the same method has yielded lower thresholds, suggesting that cutaneous and corneal nociceptors' temperature thresholds are comparable (Ashley et al., unpublished data). The only physiological characteristic that differed between the different corneal receptor types was the larger afterhyperpolarisation amplitude in the polymodal receptors compared to those that showed only mechanical sensitivity. Polymodal nociceptors have characteristically large, broad and slow action potentials, with similar differences reported for mammalian receptors [7]. All of the other action potential properties measured in the corneal nociceptors were similar to those found in trout cutaneous receptors [14], reptilian cutaneous receptors [6], and mouse corneal receptors [7] suggesting that they are evolutionarily conserved.

Two of the three types of receptors present in the mammalian cornea were found in the trout: mechanosensitive receptors and polymodal nociceptors, including mechanothermal nociceptors and mechanochemical receptors. However, none of these receptors responded to cold between $4^{\circ} \mathrm{C}$ and $-8^{\circ} \mathrm{C}$, indicating that trout lack cold sensitive neurons in the cornea. Fish are poikilothermic and many species live in temperatures below the mammalian nociceptive cold threshold of $4^{\circ} \mathrm{C}$. Hence, it might be maladaptive to possess a nociceptive system that responded to such low temperatures. Rainbow trout easily tolerate temperatures between $0^{\circ} \mathrm{C}$ and $25^{\circ} \mathrm{C}$, so it is to be expected that their nociceptors would have temperature thresholds above this range [12,14]. In contrast, mammals need to maintain a constant body temperature and exposure to low temperatures can cause tissue damage. It is possible that higher vertebrates have evolved a much more comprehensive nociceptive system in order to detect these low, damaging temperatures and have subsequently evolved cold nociceptors possibly during the transition from poikilothermy to homeothermy. It would be interesting to examine a tropical teleost such as the zebrafish, with tolerance limits from $20^{\circ} \mathrm{C}$ to $30^{\circ} \mathrm{C}$; cold might be particularly damaging to species that require higher environmental temperatures.

None of the receptors were found on the pupil of the eye and were only located on the area over the iris. The pupil consists of an unpigmented squamous epithelium, a membranous stroma, and a thin endothelium surrounded by the iris. The iris, a continuation of the choroid body that contains the richly 
vascularized reté mirabile, projects in a thin layer over the anterior surface of the lens and separates aqueous and vitreous chambers with its leading edge defining the pupil. In mammals, nociceptors are found over the whole surface of the cornea [9] suggesting that a more comprehensive nociceptive system has evolved in terrestrial vertebrates as suggested by previous work on fish due to increased chance of injury in an aerial environment $[12,14]$. It might be especially detrimental if damage occurred to the iris that forms part of the richly vascularised tissue of the fish eye and, therefore, it is adaptive that nociceptors are located here. Fish live in an aqueous environment that filters light out and perhaps extra neural tissue in the pupil would obscure penetration of light.

The polymodal units gave the most robust response to acid stimulation with peak rates rising well above 100 spikes/s. Perhaps this reflects the importance of this stimulus type to the fish. Normally in humans and other mammals this concentration of acid would only excite nociceptors if injected subcutaneously and application to healthy skin would have no effect [10]. This suggests that the fish cornea is porous allowing acid to penetrate to the layers of the cornea containing free nerve endings. This could have serious implications for fish exposed to noxious chemicals in their environment since the nociceptive experience may be relatively greater than mechanical damage or a significant increase in water temperature.

The presence of nociceptors on the cornea of fish has relevance for welfare since damage to the eye from mechanical, heat or chemical stimuli may excite nociceptors that would give rise to the sensation of pain in humans. The potential for pain in fish has been explored in trout and studies have shown prolonged, complex behavioural responses to noxious stimulation that indicate an adverse experience $[15,16]$. These responses are reduced by morphine administration [13]. Laboratory studies have shown that mechanical damage, toxic substances, parasites, UV damage and changes in water salinity affect the cornea resulting in low growth and poor condition factor and, in some cases, death $[2,4,5]$. Given the high sensitivity of corneal nociceptors, the impact of eye damage should be given careful consideration by examining responses in vivo and by further physiological characterisation.

\section{Acknowledgments}

We are grateful to Jonathan R. Banks for assistance with the electrophysiological set-up. This research was funded by a BBSRC Research Grant (SS19809).

\section{References}

[1] M.C. Acosta, C. Belmonte, J. Gallar, Sensory experiences in humans and single unit activity in cats evoked by polymodal stimulation of the cornea, J. Physiol. 534 (2001) 511-525.

[2] M.J. Doughty, A.P. Cullen, C.A. Monteith-McMaster, Aqueous humour and crystalline lens changes associated with ultraviolet radiation or mechanical damage to corneal epithelium in freshwater rainbow trout eyes, J. Photochem. Photobiol. B 41 (1997) 165-172.

[3] H.W. Ferguson,V.E. Ostland, D.D. MacPhee, J.S. Lumsden, P.J. Byrne, D.J. Speare, No mucus skin disease of rainbow trout, Oncoryhnchus mykiss—a case report, J. Fish Dis. 18 (1995) 49-57.

[4] M.A. Garcia-Abiado, M. Penn, K. Dabrowski, Case study on eye abnormalities in tank reared hybrid walleyes, Aquacult. Res. 37 (2006) 443-448.

[5] A.H. Larsen, J. Bresciani, K. Buchmann, Pathogenicity of Diplostomum cercariae in rainbow trout, and alternative measures to prevent diplostomosis in fish farms, Bull. Eur. Assoc. Fish Pathol. 25 (2005) 20-27. 
[6] Y. Liang, S. Terashima, Physiological properties and morphological characteristics of cutaneous and mucosal mechanical nociceptive neurons with $A-\delta$ peripheral axons in the trigeminal ganglia of crotaline snakes, J. Comp. Neurol. 328 (1993) 88-102.

[7] M. López de Armentia, C. Cabanes, C. Belmonte, Electrophysiological properties of identified trigeminal ganglion neurons innervating the cornea of the mouse, Neuroscience 101 (2000) 11091115.

[8] B. Lynn, The fibre composition of cutaneous nerves and the classification and response properties of cutaneous afferents, with particular reference to nociception, Pain Rev. 1 (1994) 172-183.

[9] M.B. Maclver, D.L. Tanelian, Structural and functional specialisation of $A \delta$ and $C$ fiber free nerve endings innervating rabbit corneal epithelium, J. Neurosci. 13 (1993) 4511-4524.

[10] V. Martinez, S. Thakur, J.S. Mogil, Y. Tache, E.A. Mayer, Differential effects of chemical and mechanical colonic irritation to behavioural pain response to intraperitoneal acetic acid in mice, Pain 81 (1999) 179-186.

[11] M.A. Pozo, F. Cervero, Neurons in the rat spinal trigeminal complex driven by corneal nociceptors: receptive-field properties and effects of noxious stimulation of the cornea, J. Neurophysiol. 70 (1993) 2370-2378.

[12] L.U. Sneddon, Anatomical electrophysiological analysis of the trigeminal nerve of the rainbow trout, Onchorynchus mykiss, Neurosci. Lett. 312 (2002) 167-171.

[13] L.U. Sneddon, The evidence for pain perception in fish: the use of morphine as an analgesic, Appl. Anim. Behav. Sci. 83 (2003) 153-162.

[14] L.U. Sneddon, Trigeminal somatosensory innervation of the head of the rainbow trout with particular reference to nociception., Brain Res. 972 (2003) 44-52.

[15] L.U. Sneddon, V.A. Braithwaite, M.J. Gentle, Do fish have nociceptors: evidence for the evolution of a vertebrate sensory system, Proc. Roy. Soc. Lond. B 270 (2003) 1115-1122.

[16] L.U. Sneddon, V.A. Braithwaite, M.J. Gentle, Novel object test: examining pain and fear in the rainbow trout, J. Pain 4 (2003) 431-440.

[17] M. Whitear, The question of free nerve endings in the epidermis of lower vertebrates, Acta Biol. Hung. 34 (1983) 303-319 